\title{
Kombinerte stillingers betydning for sykepleiere som veileder studenter i praksisstudier
}

Marta Grongstad

Førstelektor, studieleder bachelor sykepleie og leder ekstern samhandling

Fakultet for helsefag, VID vitenskapelige høgskole, Oslo

Kari Birkelund Olsen

Førstelektor og assisterende instituttleder sykepleie

Institutt for helse- og omsorgsfag, Universitetet i Troms $\varnothing$ - Norges arktiske universitet,

Tromsø

Tove Aminda Hanssen

Fag- og forskningssykepleier og professor

Hjerte- og lungeklinikken, Universitetssykehuset Nord-Norge, Troms $\emptyset$ og Institutt for helseog omsorgsfag, Universitetet i Troms $\varnothing$ - Norges arktiske universitet, Troms $\varnothing$

Kombinerte stillinger

Praksisveiledning

Veiledningskompetanse

Læring i praksisstudier

Sykepleieveiledning

Sykepleien Forskning 202015 (82933) (e-82933)

DOI: 10.4220/Sykepleienf.2020.82933

\section{Sammendrag}

Bakgrunn: Universitetet i Troms $\varnothing$, Norges arktiske universitet, i samarbeid med Universitetssykehuset Nord-Norge etablerte i 2011 kombinerte stillinger innen sykepleie. Hovedmålet med etableringen var å imøtekomme endringer i helsetjenesten, styrke samarbeidet mellom sykepleierutdanningen og sykehuset om studentenes kliniske praksisstudier og knytte ansatte i begge institusjonene tettere sammen for å fremme praksisnær undervisning og veiledning for studentene. 
Hensikt: Å få mer kunnskap om betydningen de kombinerte stillingene har for sykepleiere som veileder sykepleierstudenter i praksisstudier.

Metode: Studien har et kvalitativt design, og data er samlet inn gjennom tre fokusgruppeintervjuer og et enkeltintervju. Informantene er sykepleiere som veileder studenter i sykehuset, som arbeider på avdelinger hvor det er ansatte i kombinerte stillinger, og som har kjennskap til de kombinerte stillingenes arbeidsoppgaver.

Resultat: De kombinerte stillingenes betydning for sykepleiernes veiledning i praksis synliggjøres gjennom to hovedkategorier: sykepleiernes behov for veiledning på veiledning og hvordan de kombinerte stillingene fremmer en kultur for veiledning. De ansatte i de kombinerte stillingene st $\varnothing t t e r$, motiverer og veileder sykepleiere gjennom planlagte veiledningsmøter der sykepleiernes behov for fagspesifikk veiledningskompetanse blir ivaretatt. Ansatte i kombinerte stillinger er initiativtakere til å bruke og utvikle nye veiledningsmodeller og til å fremme og videreutvikle avdelingskulturen for kompetanseheving innen studentveiledning.

Konklusjon: Studien viser at ordningen med kombinerte stillinger er en viktig ressurs for sykepleiere som veileder studenter i praksisstudier. En funskjonsbeskrivelse for ansatte i kombinerte stillinger bør utvikles i samarbeid mellom lederne på sykehuset og ved utdanningen for å sikre at stillingenes arbeidsoppgaver og ansvarsområde blir tydeliggjort.

Når kombinerte stillinger har vært utprøvd i Norge, er erfaringen at samarbeidet mellom utdanningen og praksisfeltet styrkes, og at det blir mer oppmerksomhet på studentenes praksisstudier (1-7).

Storbritannia har prøvd ut kombinerte stillinger gjennom flere tiår, og en litteraturgjennomgang fra 2004 viser at stillingene er viktige for samarbeidet mellom utdanning og praksis, men det understrekes at stillingenes funksjon og arbeidsoppgaver må forankres hos ledelsen for å lykkes (8).

En studie av Ousey og Gallagher viser at samarbeid mellom akademia og klinikk gjennom kombinerte stillinger er viktig for å utdanne sykepleiere (9).

\section{Kombinerte stillinger styrker kvaliteten på læring}

Kombinerte stillinger trekkes frem som et viktig virkemiddel i arbeidet med å styrke kvaliteten på studentenes læring i praksisstudier $(3,4,8,10)$. Kvaliteten på sykepleiernes veiledning har betydning for studentenes læring (11-15). 
Ansvaret for studentenes praksisstudier er delt mellom utdanningsinstitusjonene og praksisfeltet, hvor sistnevnte har ansvaret for den daglige oppfølgingen og veiledningen av studenter, og utdanningsinstitusjonene har det overordnede ansvaret for å utdanne og vurdere studentene.

Sykepleiere må mestre et stort arbeidspress og vanskelige prioriteringer i en kompleks praksishverdag, og de står ofte i skvis mellom pasientene og studentene. Mange synes dette presset er utfordrende $(13,14,16-18)$. I en norsk studie understreker praksisveiledere at tid, kompetanse og ledelsesforankring er nøkkelfaktorer for at studenter skal få gode praksisopplevelser og oppleve kvalitet på læringen (16).

\section{Forståelsen av læring}

Læring er et komplekst fenomen, og erfaringene gjennom livet har innvirkning på og betydning for hvordan man forstår veilednings- og læringsprosesser. Et sosiokulturelt syn på læring legger vekt på gjensidighet mellom personen og situasjonen i læringsprosessen (19). Lave og Wenger trekker frem betydningen av praksisfellesskapet, og at kunnskap konstrueres i samhandling med aktørene i miljøet (19).

For å forstå hvordan læring foregår, må vi være oppmerksomme på hvordan kognitive, sosiale og ferdighetsmessige aspekter virker sammen. Situasjonen eller konteksten veiledningen foregår $i$, og de materielle og menneskelige ressurser som er tilgjengelige, påvirker læringen.

Disse forholdene krever at sykepleieren som veileder har fagkunnskaper, pedagogiske ferdigheter og kommunikasjonsferdigheter (20). Sykepleierens veiledningskompetanse, motivasjon og engasjement er viktig for å underst $\varnothing$ tte studentenes læringsprosesser (13, 15, 2022).

\section{Kombinerte stillinger}

Sykepleierutdanningen ved Universitetet i Troms $\varnothing$ - Norges arktiske universitet (UiT) i samarbeid med Universitetssykehuset Nord-Norge (UNN) etablerte i 2011 kombinerte stillinger innen sykepleie. De 17 kombinerte stillingene innehas av ti sykepleiere ved UNN og sju lærere ved sykepleierutdanningen.

Stillingenes omfang er 20 prosent ressurs, og de er organisert i klinikkvise team med en til to sykepleiere og en lærer i hvert team (3). 
De ansatte i de kombinerte stillingene samarbeider med sine team om å planlegge arbeidsoppgaver for hvert studieår. De rapporter skriftlig etter endt gjennomføring $(3,23)$. Arbeidsoppgavene til de ansatte i de kombinerte stillingene skiller seg fra praksisveilederens og lærerveilederens oppgaver og innebærer en kombinasjon av student- og veilederoppfølging og deltakelse i fagutviklingsprosjekter.

De fremmer koordinering av studenter, undervisning og veiledning, samarbeider med andre faggrupper om tverrprofesjonell samarbeidslæring og deltar i ulike råd og utvalg. Arbeidsoppgavene i de kombinerte stillingene omfatter et særlig ansvar for å veilede og følge opp praksisveilederne og bidra aktivt med å utvikle nye praksisog veiledningsmodeller (10).

\section{Hensikten med studien}

Få studier har unders $\varnothing \mathrm{kt}$ hvilke prioriteringer og arbeidsoppgaver kombinerte stillinger ivaretar når det gjelder støtte til sykepleiere som veileder studenter. Vi har i tidligere arbeider unders $\varnothing \mathrm{kt}$ erfaringene med kombinerte stillinger og hvilke oppgaver de som er i kombinerte stillinger, ivaretar (3).

I denne studien $\varnothing$ nsket vi å få frem erfaringene til sykepleierne som veileder studenter i praksis. Hensikten var å få mer kunnskap om hvilken betydning de kombinerte stillingene har for sykepleiere som veileder sykepleierstudenter i praksisstudier.

\section{Metode}

Studien har et kvalitativt design med bruk av fokusgruppeintervjuer og ett individuelt intervju. Informantenes erfaringer, subjektive opplevelser og synspunkter uttrykkes og videreutvikles gjennom felles dialog og interaksjon med intervjueren (24). Intervjueren setter søkelyset for intervjuet, stiller spørsmål og bærer samtalen. Gruppedynamikken fremskaffer rikere data enn ved individuelle intervjuer $(24,25)$.

\section{Utvalg}

Vi ønsket å rekruttere sykepleiere som hadde veiledet studenter i løpet av de to siste årene, og fra et bredt utvalg av klinikkene som hadde kombinerte stillinger. Vi planla å rekruttere via avdelingssykepleierne, som fikk informasjonsmateriell og ble bedt om å henvende seg til sykepleiere ved avdelingen. 
Til tross for oppfølging og purringer ble det kun rekruttert én sykepleier på denne måten. Vi besluttet derfor å gå via de ansatte i kombinerte stillinger og be dem om å informere sykepleiere om studien. Vi fikk navn og e-postadresse til de som sa seg villige, og sendte ut informasjon og invitasjon til å delta.

\section{Datasamling og gjennomføring}

I forkant av intervjuene fylte informantene ut et spørreskjema om kjønn, alder, antallet år som sykepleiere og antallet år i jobb på sykehuset, stillingsstørrelse og veiledningserfaring.

Vi utførte et prøveintervju med tre deltakere for å få erfaring med intervju i gruppesammenheng samt prøve ut intervjuguiden og samarbeidet mellom moderatoren og observatøren. Intervjuguiden besto av åpne spørsmål om sykepleiernes erfaringer med de kombinerte stillingene.

Temaene var informantenes kjennskap til og erfaringer med de kombinerte stillingene, herunder arbeidsoppgaver og samarbeid knyttet til studentveiledningen, og om det var noe de savnet.

Vi gjennomførte tre fokusgruppeintervjuer med tre deltakere i det første intervjuet, fire i det andre, to i det tredje og en informant i det siste intervjuet. Det var to observatører, der andreforfatteren deltok i de tre første intervjuene og tredjeforfatteren i det siste.

Førsteforfatteren var moderator, ledet intervjuene og oppmuntret informantene til diskusjon. Moderatoren hadde god kjennskap til ordningen med de kombinerte stillingene, mens observatørene hadde hatt lite å gjøre med dem. Observatøren sikret distanse og fulgte opp med spørsmål mot slutten av intervjuene.

Observatøren hadde ansvaret for å ta opp samtalene $\mathrm{i}$ gruppen. Dataene kom frem underveis i samtalene som en del av interaksjonen mellom informantene og moderatorens oppfølgende spørsmål. Interaksjonen varierte i gruppene med mer enn to deltakere.

I et av fokusgruppeintervjuene kom det frem mer data som følge av samtalen mellom gruppemedlemmene enn i det andre, der deltakerne heller delte egne erfaringer uten at meddeltakernes innspill påvirket. 
I planleggingen åpnet vi opp for at det var mulig å gjennomføre flere intervjuer dersom vi hadde inntrykk av at nye momenter ville fremkomme. Etter at vi hadde gjennomført intervjuene, vurderte vi at det ikke var nødvendig. Intervjuene ble gjennomført i februar $2019 \mathrm{i}$ universitetets lokaler med lett servering, og de varte fra 6090 minutter.

\section{Dataanalyse}

Hvert gruppeintervju ble tatt opp og transkribert ordrett. Dataene fra intervjuene danner grunnlaget for analysen. Vi gjennomførte den første analysen umiddelbart etter hvert intervju i form av oppsummering og diskusjon av innholdet som kom frem.

I analysen videre benyttet vi kvalitativ innholdsanalyse inspirert av Graneheim og Lundman, som er en systematisk analyse av tekst hvor man ønsker å forstå tekstens mening og innhold til et bestemt fenomen (26). Vi leste gjennom intervjuene flere ganger for å få en forståelse av innholdet og identifisere meningsenheter i materialet.

Vi sammenfattet de kondenserte meningene til undertemaer og fortolket dem gjennom å stille analytiske spørsmål til innholdet. Spørsmålene var basert på våre erfaringer og teorier, og knyttet til hensikten med studien.

Vi benyttet NVivo i analysearbeidet som hjelp til å kategorisere meningsenheter, kondensere meninger og komme frem til hovedkategorier og tema. Siste fasen av analysen var å gi ny mening til dataene gjennom å forstå og fortolke de innsamlede dataene (26).

Tabell 1 viser et eksempel på analyseprosessen fra meningsenhet til tema. Vi diskuterte videre analysearbeid med kondenserte meningsenheter og hovedkategorier som ledet frem til temaer, før vi oppnådde enighet. 
Tabell 1. Analyseprosessen: eksempel fra meningsenheter til tema

\begin{tabular}{|c|c|c|c|}
\hline Meningsenheter & $\begin{array}{l}\text { Kondenserte } \\
\text { meningsenheter }\end{array}$ & Hovedkategori & Tema \\
\hline $\begin{array}{l}\text { «Hun [sykepleier i kombinert stilling] er jo på nabo- } \\
\text { avdelingen, så da kan jeg bare gå bort og banke på døren } \\
\text { hennes og sette meg ned og prate litt med henne om det } \\
\text { som vi på en måte har [...] eller det jeg plages med da. } \\
\text { Og så kan hun si noe om hva hun tenker. Og så kan jeg like } \\
\text { greit skrive en mail til henne [lærer i kombinert stilling] } \\
\text { eller ringe henne. Det synes jeg var veldig fint fordi hun } \\
\text { vet hva universitetet forventer av studentene.» }\end{array}$ & $\begin{array}{l}\text { Kombinerte stillinger } \\
\text { gir sykepleieren } \\
\text { veiledning og st } \varnothing t t e \\
\text { i veilederrollen. }\end{array}$ & $\begin{array}{l}\text { Veiledning på } \\
\text { veiledning }\end{array}$ & $\begin{array}{l}\text { De kombinerte } \\
\text { stillingene ivaretar } \\
\text { sykepleiernes } \\
\text { behov for } \\
\text { fagspesifikk } \\
\text { veilednings- } \\
\text { kompetanse }\end{array}$ \\
\hline $\begin{array}{l}\text { «Jeg synes det er helt fantastisk å få litt veiledning og } \\
\text { sørge for at en gir studentene den riktige veiledningen, } \\
\text { og en vet litt hva de har lov til å gjøre spesielt innenfor } \\
\text { alt ifra legemidler til prosedyrer og hva de kan gjøre, og } \\
\text { hva de ikke kan gjøre. og generelt hva forventes en av } \\
\text { studentene.» }\end{array}$ & $\begin{array}{l}\text { Sykepleierens behov } \\
\text { for } \varnothing \text { kt veiledning- } \\
\text { skompetanse. }\end{array}$ & & \\
\hline $\begin{array}{l}\text { «Men jeg synes jo at jeg på en måte har mest bruk for } \\
\text { henne når det oppstår noe. Ikke sant, at hvis det er noe } \\
\text { så har jeg henne som en sparringpartner. Og så finner } \\
\text { hun ut ting og kan gi meg [beskjed om at jeg] gjør det } \\
\text { rett eller kanskje du skal gjøre det sånn. Hun er på en } \\
\text { måte min veileder i mange tilfeller.» }\end{array}$ & $\begin{array}{l}\text { De kombinerte } \\
\text { stillingene kan } \\
\text { oppsøkes ved behov } \\
\text { og når noe oppstår. }\end{array}$ & & \\
\hline $\begin{array}{l}\text { «Jeg føler kanskje at hun i kombinert stilling fra uni- } \\
\text { versitetet bruker veiledningssamtalene til å prate om } \\
\text { hvordan veilede, hva er en god veileder, og hvilke for- } \\
\text { ventninger har studentene til oss som veiledere, og hva } \\
\text { slags forventninger skal vi ha til studentene? Under de } \\
\text { samtalene som vi har med de kombinertstillingene, så er } \\
\text { det ofte snakk om veiledning som en læringsprosess.» }\end{array}$ & $\begin{array}{l}\text { De kombinerte } \\
\text { stillingene inform- } \\
\text { erer om studiet, krav } \\
\text { og forventninger til } \\
\text { studentene og om } \\
\text { veiledningsprosessen. }\end{array}$ & & \\
\hline
\end{tabular}

\section{Etiske betraktninger}

Vi informerte skriftlig om studien og innhentet også skriftlig informert samtykke fra alle informantene. De fikk informasjon om at dataene ble anonymisert, og om at informantene når som helst kunne trekke seg fra unders $\varnothing$ kelsen.

Personidentifiserbare opplysninger ble anonymisert i transkriberingen, og dataene ble lagret etter gjeldende retningslinjer. Studien ble meldt inn til og godkjent av Norsk senter for forskningsdata (NSD) (prosjektnummer 57847), som ivaretar personvern for forskningsprosjekter ved UiT.

\section{Resultat}

Til sammen ti sykepleiere, hvorav én mann, i alderen 25-54 år fra ulike klinikker deltok i studien. Informantene hadde vært veiledere for studenter fra to til 34 år. To hadde videreutdanning og tre hadde formell veilederutdanning.

De hadde ulik erfaring og ansvar i veiledningen av sykepleierstudenter, men alle hadde veiledet studenter i praksisstudier det siste året. Alle informantene hadde kjennskap til kombinerte stillinger, men hadde ulik grad av kjennskap til funksjonen og hva den innebar. 
To hovedkategorier trådte frem i materialet for måten de kombinerte stillingene har betydning for sykepleiernes veiledning av sykepleierstudenter: «veiledning på veiledning» og «å fremme en kultur for veiledning».

\section{Veiledning på veiledning}

Informantene trakk i hovedsak frem hvor viktig det var å få fagspesifikk veiledningsst $\varnothing t t e$ som omhandlet informasjon om studiets fagplan og avklaringer om krav, ansvar og forventninger til hva studentene skal lære. Videre hadde de et $\varnothing n s k e$ om å få hjelp til å sette veiledningen inn i en faglig kontekst:

«Å få mer sånn verktøy med hvordan vi kan få studentene til å skjønne [...] at sykdomslæren og alt det andre de skal lære, ikke er for å bestå eksamen, det er for at du skal faktisk - det skal være forsvarlig at du går ut i virkeligheten, og skal ta deg av mennesker. At de skal lære seg å tenke på hjertesvikt, det er ikke bare for å få A eller B, men det er for at du skal kunne vite hva som skjer når de ikke får puste.»

Informantene trakk også frem hvor viktig det er å få hjelp til å finne gode læringssituasjoner, og hvor nyttig det er å kunne kontakte de ansatte i de kombinerte stillingene når det oppstår utfordringer i den daglige veiledningen av studentene.

\section{三 «Møtepunktene fungerte som mulighet for å få veiledning på veiledning.»}

Informantene fortalte at ved flere klinikker arrangerte ansatte i kombinerte stillinger formelle møter for sykepleieveilederne. Møtepunktene fungerte som mulighet for å få veiledning på veiledning. På klinikker der sykepleierne mente det fungerer godt, var det faste møter i starten, midten og mot slutten av studentenes praksisperioder.

I møtene fokuserte de på hvor viktig det er med veiledningskompetanse og kunnskaper om ulike læringsaktiviteter og veiledningsmetoder. Informantene fortalte at de ansatte i kombinerte stillinger demonstrete ulike veiledningssituasjoner som utgangspunkt for refleksjon og diskusjon blant sykepleierne som deltok på møtene. Sykepleierne opplevde dette som lærerikt og støttende. 
Informantene ga uttrykk for at de kombinerte stillingene bidrar til å rette oppmerksomheten mot deres behov for veiledningskompetanse, og etterspurte mer formell kompetanse i veiledning.

Informantene mente at det er viktig å prøve ut nye modeller for veiledning og begrunnet det med at det er mange studenter, at det er stor slitasje på sykepleiere som skal veilede, og at det er viktig å prøve noe nytt.

Veiledningsmodeller de selv hadde da de var studenter, var oftest basert på en-til-en-forhold mellom sykepleieveileder og student etter mester-svenn-modellen. Denne modellen mente de ofte er for sårbar dersom forholdet mellom veilederen og studenten ikke fungerer så godt, eller når veilederen blir borte av ulike årsaker.

Det kom tydelig frem at de ansatte i de kombinerte stillingene har betydning som initiativtakere for å bruke nye veiledningsmodeller i praksis. Noen ga uttrykk for at de selv hadde tatt initiativ, men $\varnothing$ nsket mer st $\varnothing t t e$ fra de kombinerte stillingene for å få dette til.

Informantene fortalte om ulike veiledningsmodeller de hadde vært med og prøvd ut. De nevnte parpraksis, studentdrevne team og ulike tverrprofesjonelle veiledningsmodeller, der studenter fra ulike profesjoner hadde deltatt.

\section{Å fremme en kultur for veiledning}

Informantene uttrykte tydelig at de ønsket at de ansatte i de kombinerte stillingene deltok aktivt med å bygge veiledningskultur i praksis, og at dette var viktig for sykepleiernes engasjement, motivasjon og kompetanseheving innen veiledning.

Informantene fortalte at mange veiledere er opptatt av å være gode veiledere. Samtidig viser våre funn at ikke alle veilederne benyttet seg av de kombinerte stillingenes tilbud om veiledning på veiledning. Informantene fortalte at noen sykepleiere var negative til og helst ville slippe å veilede studenter, samtidig som de opplevde at det var dårlig tilrettelagt for å ha veiledningsansvar på avdelingen. 
Flere informanter formidlet at det ikke var kultur på avdelingene for kompetanseheving innen veiledning. De ga uttrykk for at det var litt for mye opp til den enkelte sykepleieren, at noen var lite motiverte, og at de som ikke ble med på veiledningsmøtene eller kurs, ikke visste hva de gikk glipp av:

«Det er på en måte først nå [...] at jeg virkelig har oppsøkt det og skjønt hvor mye jeg kan få, hvor mye informasjon jeg kan få om å være en god veileder.»

De ønsket at de kombinerte stillingene skulle bidra til å få flere med.

\section{$\equiv \ll$ Flere informanter formidlet at det ikke var kultur på avdelingene for kompetanseheving innen veiledning.»}

Flere informanter fortalte at før studentene kommer til avdelingen, gjennomfører de ansatte i de kombinerte stillingene planleggingsm $\varnothing$ ter med veilederne. Her diskuteres tidligere erfaringer, og de planlegger oppstartsdagene. På noen avdelinger er det satt av tid til kurs, og det forventes at sykepleierne deltar i de tilbudene som finnes.

Ved flere avdelinger fortalte informantene at det ikke var satt av tilstrekkelig med tid til veiledning. Flere informanter etterlyste mer engasjement fra ledelsen, og enkelte trakk frem at når lederen mangler veiledningskompetanse, vektlegger heller ikke sykepleierne veiledningen. En informant uttalte følgende:

«På min avdeling så er det veldig dårlig med akkurat dette her med studenter og veiledning. Jeg tror på en måte det ikke er kultur for å være med på de veiledningstimene. Og jeg tror egentlig det er litt fordi at folk generelt ikke helt vet hva det er, og dermed ikke helt ser behov for det.»

\section{Diskusjon}

Resultatene synliggjør sykepleiernes behov for fagspesifikk veiledningskompetanse, som beskrives som kunnskap om utdanningens fagplan og læringsutbytte for praksisperioden, og om hvilke krav, ansvar og forventninger sykepleierne kan stille til studentene. Denne informasjonen har betydning for dem som veileder, da studentene som kommer til avdelingen, er på ulike stadier i studieprogrammet. 
Noen har hatt praksisstudier på sykehus tidligere og kan være studenter i siste studieåret, mens andre er ute i praksisstudier for første gang, og har akkurat startet på andre studieåret. For å kunne gi veiledning er det vesentlig at sykepleieren har kjennskap til hva som kan forventes av den enkelte studenten, og at det tilrettelegges for en god mottakelse av studentene når de kommer ut i praksis $(4,11,13,16,18)$.

\section{三 «Informantene ønsket egne fora for å diskutere og utveksle erfaringer i veilederrollen.»}

Informantene ønsket egne fora for å diskutere og utveksle erfaringer i veilederrollen og reflektere over hva som er god veiledning $(13,27)$. Veiledningsmøtene som de ansatte i de kombinerte stillingene arrangerte, har betydning for sykepleiernes veiledning av studenter da de ivaretar sykepleiernes behov for fagspesifikk veiledningsst $\varnothing t t e$.

Informantene opplevde at lærerveilederne fra sykepleierutdanningen hadde liten tid avsatt til å støtte og veilede sykepleierne.

Informantene $\varnothing$ nsket mer oppmerksomhet på å prøve ut nye veiledningsmodeller, og at de ansatte i de kombinerte stillingene tok ansvaret for dette. De burde legge mer vekt på å utvikle nye veiledningsmodeller gjennom forbedringsprosjekter i praksis. Her hadde de ansatte i kombinerte stillinger vist seg å være sentrale $(3,10)$.

\section{Kombinerte stillinger må tydeliggjøres}

Vår studie viser at det var ulik grad av kjennskap til funksjonen og arbeidsoppgavene i de kombinerte stillingene. Sykehuset er en stor organisasjon med mange ansatte og høy turnover. Det er viktig å samarbeide om å etablere kombinerte stillinger og beskrive hensikten og arbeidsoppgavene $(1-3,8,23)$.

Ansvaret for læringsmiljøet for studentene må gjøres tydelig, og kvaliteten i praksisstudiene må sikres. Disse faktorene må inn i samarbeidsavtaler mellom utdanningsinstitusjoner og praksisfelt, slik det påpekes i aktuelle rapporter $(14,16,18)$ og i nasjonale forskrifter $(28,29)$. 


\section{Veiledningskompetansen hadde ulik prioritering}

Studien viser at klinikkene hadde ulik kultur for å utvikle veiledningskompetanse. Flere av informantene uttrykte at det er for mye opp til den enkelte sykepleier. I en hektisk arbeidshverdag kan det være problematisk for lederne å prioritere kompetanseutvikling innen veiledning. Ledere ses som sentrale i å kvalitetssikre veiledningen, st $\varnothing t t e ~ v e i l e d e r e n$ samt sikre tid, veiledningskompetanse og ressurser til å veilede $(14,16,18)$.

Manglende struktur og st $\varnothing t t e$ fra ledelsen gjør at veiledning kan bli et individuelt ansvar, noe som kan oppleves som belastende. Det kan også føre til at kvaliteten på studentenes praksis avhenger av hvem som er deres praksisveileder, og hvilken kompetanse vedkommende har (4).

\section{«De kombinerte stillingene er en viktig ressurs i arbeidet med å etablere en kultur for veiledning.»}

En australsk studie viste at manglende program og plan for veilederopplæringen resulterte i at sykepleierne opplevde høyt arbeidspress, lite samarbeid med kollegaene om veiledning, liten tid til veiledning og mangelfull opplæring (31).

Vår studie viser at de kombinerte stillingene er en viktig ressurs i arbeidet med å etablere en kultur for veiledning, men det fordrer en tett dialog med lederne.

\section{Veiledningskompetanse er etterspurt}

Resultatene våre er i tråd med nasjonale og internasjonale unders $\varnothing$ kelser som viser at praksisveiledere ettersp $\varnothing \mathrm{r}$ pedagogiske kvalifikasjoner og veiledningskompetanse (13-15, $17,31,32)$.

$\AA \varnothing$ øe veiledningskompetansen har stor betydning for sykepleierstudentenes læring i praksisstudier (13, 14, 16, 22) og fører til at praksisveilederens veiledningsatferd, kunnskaps- og læringssyn endres på vesentlige områder, og er den viktigste faktoren for å gjennomføre planlagt veiledning.

De kombinerte stillingene bidro til bedre veiledningskompetanse og mer oppmerksomhet på studentveiledning. Veiledere med formell veilederutdanning uttrykte at de opplevde $\varnothing \mathrm{kt}$ trygghet i hvordan de skulle møte studentene, og hvordan de kunne stille $\operatorname{krav}(13,14)$. 
De fleste utdanningsinstitusjonene tilbyr veilederopplæring, og praksisveilederen bør som hovedregel ha formell veiledningskompetanse (29).

\section{Studiens begrensninger}

Vi rekrutterte informantene via de kombinerte stillingene. I analysen var vi spesielt oppmerksom på om det kunne ha forekommet en selektiv utvelgelse av informanter. Både positive, men også kritiske momenter kom frem og informantene hadde variert erfaring fra samarbeid med de ansatte i de kombinerte stillingene. Derfor mener vi at det ikke er sannsynlig at de resultatene som er fremkommet, skyldes utvalgsskjevhet.

Vi hadde planlagt å ha fire til fem informanter i hver fokusgruppe. På grunn av frafall ble det kun henholdsvis en og to sykepleiere i to av gruppene. Vi valgte likevel å gjennomføre de planlagte intervjuene, selv om vi fikk færre data i disse gruppene. Vi mener at disse intervjuene bidro med verdifulle data til studien, og derfor gjennomførte vi ikke flere intervjuer.

\section{Konklusjon}

Studien viser at de kombinerte stillingene er en viktig ressurs for sykepleiere som veileder studenter i praksisstudier. De ansatte i disse stillingene st $\varnothing$ tter, motiverer og veileder sykepleiere når de trenger det, og gjennom planlagte veiledningsmøter, slik at sykepleiernes behov for fagspesifikk veiledningskompetanse blir ivaretatt.

De ansatte i de kombinerte stillingene er initiativtakere til å bruke og utvikle nye veiledningsmodeller og er en viktig ressurs i arbeidet med å fremme og videreutvikle en avdelingskultur for veiledning og kompetanseheving innen studentveiledning.

Vi anbefaler å etablere kombinerte stillinger i praksis for å styrke studentveiledningen. På sikt kan dette bidra til å bedre rekrutteringen, da vi har erfaring med at studenter vender tilbake til avdelinger hvor de har gode praksiserfaringer.

Det er behov for mer forskning på bruken av kombinerte stillinger. Slik forskning kan inkludere kunnskap om studentenes og lærerveiledernes erfaringer med kombinerte stillinger og om innvirkningen på studentenes læringsmiljø. 


\section{Referanser}

1. Universitets- og høgskolerådet. Kvalitet i praksisstudiene i helse- og sosialfaglig høyere utdanning: Praksisprosjektet. Sluttrapport fra et nasjonalt utviklingsprosjekt gjennomført på oppdrag fra KD i perioden 2014-2015. Oslo: Universitetsog høgskolerådet; 2016.

2. Gadgil I, Grongstad M, Isaksen L, Lyngdal $\varnothing$. Forbedringsforslag av ordningen med kombinerte stillinger. Troms $\varnothing$ : Felles utdanningsutvalg ved Universitetssykehuset Nord-Norge og UIT - Norges arktiske universitet; 2015.

3. Grongstad M, Olsen KB, Hanssen TA. Kombinerte stillinger bygger bro mellom utdanning og praksis. Sykepleien. 2018;106(65022):e-65022. DOI:

10.4220/Sykepleiens.2018.65022

4. Caspersen J, Kårstein A. Kvalitet i praksis: oppfatninger om kvalitet blant praksisveiledere. Oslo: NIFU; 2013. NIFUrapport 2013:14.

5. Tennøe EH. Lærere i teori og praksis. Sykepleien. 2007;95(7):74-5. DOI: 10.4220/sykepleiens.2007.0013

6. Frigstad S, Nøst T, Blekken L. Kombinerte stillinger gir faglig gevinst. Sykepleien. 2015;103(6):52-5. DOI: $\underline{10.4220 / \text { Sykepleiens.2015.54439 }}$

7. Skaalvik M, Borch I, Hokland K, Tande M, Foss I. Evaluering av ordningen med kombinerte stillinger for helsefaglige utdanninger ved UNN og UiT. Troms $\varnothing$ : Felles utdanningsutvalg ved Universitetssykehuset Nord-Norge og UiT - Norges arktiske universitet; 2014.

8. Williamson GR. Lecturer practitioners in UK nursing and midwifery: what is the evidence? A systematic review of the research literature. Journal of Clinical Nursing. 2004;13(7):787-95.

9. Ousey K, Gallagher P. The clinical credibility of nurse educators: time the debate was put to rest. Nurse Education Today. 2010;30(7):662-5. 
10. Grongstad M, Kuosa K. Praksisstudier i

spesialisthelsetjenesten. Rapport fra arbeidsgruppe med mandat om å utvikle sykepleierstudentenes praksisstudier i UNN. Troms $\varnothing$ : Felles utdanningsutvalg ved Universitetssykehuset Nord-Norge og UiT - Norges arktiske universitet; 2018.

11. Skaalvik MW. Bedre kvalitetssikring av praksis.

Sykepleien. 2015;103(4):58-61. DOI:

$10.4220 /$ Sykepleiens.2015.53650

12. Aase EL. Avdelingslederes betydning for læringsmiljøet til sykepleierstudenter i sykehjem. Sykepleien Forskning. 2019;14(77617):(e-77617). DOI: $\underline{10.4220 / \text { Sykepleienf.2019.77617 }}$

13. Hauge KW, Maas $\varnothing$ AG, Barstad J, Elde HS, Karlsholm G, Stamnes A, et al. Kvalitet og kompetanse i praksisveiledning av studenter i helse- og sosialfag i spesialhelsetjenesten. Molde: Møreforsking / Høgskolen i Molde; 2015. Rapport nr. 1514 .

14. Maas $\varnothing$ A-G. Kvalitet og kompetanse i praksisveiledning av vernepleier- og sykepleierstudenter $i$

kommunehelsetjenesten i Nord-Trøndelag. Namsos: Senter for omsorgsforskning, midt; 2016. Rapportserie 2016:8.

15. Pramila-Savukoski S, Juntunen J, Tuomikoski AM, Kääriäinen M, Tomietto M, Kaučič BM, et al. Mentors' selfassessed competence in mentoring nursing students in clinical practice: a systematic review of quantitative studies. Journal of Clinical Nursing. 2020;29(5-6):684-705.

16. Kårstein A, Caspersen J. Praksis i helse- og sosialfagutdanningene. En litteraturgjennomgang. Oslo: NIFU; 2014. Rapport 16/2014.

17. Aigeltinger E, Haugan G, Sørlie V. Utfordringer med å veilede sykepleierstudenter i praksisstudier. Sykepleien Forskning. 2012;7(2):160-6. DOI:

10.4220/sykepleienf.2012.0084

18. Uppsata SE, Iversen A, Skommesvik S, Nordhaug M, Onstad RF, Haukeland M, et al. I en akseptert skvis mellom systemkrav og kvalitetskrav? Leders perspektiv på kvalitet i praksisveiledning. I: Tveiten S, Iversen A, red. Veiledning i høyere utdanning. En vitenskapelig antologi. Bergen:

Fagbokforlaget; 2018. s. 121-36. 
19. Lave J, Wenger E. Situeret læring - og andre tekster.

København: Reitzel; 2003.

20. Olsen KB, Knudsen LB. Også det å se pasienten oppe i alt dette. En studie av sykepleierstudenters erfaringer med å lære sykepleie i praksisstudier på sykehus. Nordisk sygeplejeforskning. 2015;(4):315-28.

21. Maas $\varnothing$ A-G. Å se med hjertets $\varnothing y n e$. En fenomenologisk studie av sykepleierstudenters samspill med praksisveileder i en kirurgisk sengepost med hensyn til oppøving og utvikling av et faglig og reflekterende skjønn. (Doktoravhandling.) Trondheim: Norges teknisk-naturvitenskapelige universitet, Fakultet for samfunns- og utdanningsvitenskap, Institutt for pedagogikk og livslang læring; 2014.

22. Egede-Nissen V, Skommesvik S. Veiledning som grunnlag for kompetanseutvikling. I: Tveiten S, Iversen A, red. Veiledning i høyere utdanning. En vitenskapelig antologi. Bergen: Fagbokforlaget; 2018. s. 36-49.

23. Nikolaisen M, Konradsen AH, Barge B, Reitan E, TufteGerhardsen G, Øien L, et al. Rapport fra arbeidsgruppe om kombinerte stillinger. Troms $\varnothing$. Felles utdanningsutvalg ved Universitetssykehuset Nord-Norge og UiT - Norges arktiske universitet; 2017.

24. Malterud K. Kvalitative forskningsmetoder for medisin og helsefag. 4 utg. Oslo: Universitetsforlaget; 2017.

25. Olsen TA. Hvordan gjøre en vellykket datainnsamling: diverse feller man kan gå i når man samler inn data ved hjelp av fokusgruppeintervju. Sykepleien Forskning. 2011;6(3):2926. DOI: 10.4220/Sykepleienf.2019.57456

26. Graneheim UH, Lundman B. Qualitative content analysis in nursing research: concepts, procedures and measures to achieve trustworthiness. Nurse Educ Today. 2004;24(2):105-12.

27. Alvsvåg $\mathrm{H}, \mathrm{F} \varnothing$ rland $\mathrm{O}$, Abrahamsen B. Refleksjoner om utdanning og kunnskap i sykepleie. I: Alvsvåg H, Førland O, red. Engasjement og læring : fagkritiske perspektiver på sykepleie. Oslo: Akribe; 2007. 
28. Forskrift 15. mars 2019 nr. 412 om nasjonal retningslinje for sykepleierutdanning. Tilgjengelig fra:

https://lovdata.no/dokument/SF/forskrift/2019-03-15-412

(nedlastet 27.11.2020).

29. Forskrift 6. september $2017 \mathrm{nr} .1353$ om felles rammeplan for helse- og sosialfagutdanninger. Tilgjengelig fra:

https://lovdata.no/dokument/SF/forskrift/2017-09-06-1353 (nedlastet 27.11.2020).

30. Bogsti WB, Solvik E, Engelien RI, Moen $\varnothing \mathrm{L}$, Nordhagen SS, Struksnes S, et al. Styrket veiledning i sykepleierutdanningens praksisperioder. Vård i Norden. 2013;33(1):56-60.

31. Trede F, Sutton K, Bernoth M. Conceptualisations and perceptions of the nurse preceptor's role: a scoping review. Nurse Educ Today. 2016;36:268-74.

32. Löfmark A, Morberg Å, Öhlund L, Ilicki J. Supervising mentors' lived experience on supervision in teaching, nursing and social care education. A participation-oriented phenomenological study. Higher Education. 2009;57(1):10723. 